\title{
Organometallic Reagents for Synthetic Purposes: Tellurium
}

\author{
Nicola Petragnani*, and Wai-Ling Lo \\ Instituto de Química, Universidade de São Paulo, Av. Lineu Prestes, 748, C.P. 26077, \\ 05599-970 São Paulo, SP - Brazil
}

Received: December 16, 1997

\begin{abstract}
As principais aplicações sintéticas de reagentes contendo telúrio foram reunidas e estão apresentadas a seguir.

An overview of the most important applications of tellurium compounds in Organic Synthesis is presented.
\end{abstract}

Keywords: tellurides, organotellurium compounds

\section{Introduction}

About a quarter of a century ago, Tellurium was considered almost as an exotic element and was treated with certain diffidence by the most serious chemists. Then the explosive development of Selenium chemistry called attention to the potentiality of Tellurium analogues, resulting in studies on preparation methods for inorganic and organic tellurium compounds and particularly on their applications in Organic Synthesis. In the mid 50's, H. Rheinboldt published the first review (about 50 pages) on selenium and tellurium compounds in organic chemistry ${ }^{1 \mathrm{a}}$, then in 1990 $\mathrm{K}$. Irgolic dedicated as much as 1000 pages in a review on tellurium compounds ${ }^{1 \mathrm{~b}}$. The impressive number of publications on this subject during the last few years shows that Tellurium already plays a new role as a powerful chemical tool. Herein we present an overview of the most important applications of Tellurium compounds in Organic Synthesis.

\section{Reduction}

A large variety of organic substrates can be reduced by tellurium reagents, for instance carbonyl compounds and their $\alpha, \beta$-conjugated analogues, aryl alkenes and alkynes, nitro compounds and other nitrogenated derivatives. Compounds bearing heteroatoms can be submitted to reductive cleavage of the carbon-heteroatom bond. The most commonly used reagents are $\mathrm{H}_{2} \mathrm{Te}, \mathrm{NaHTe}, \mathrm{Na}_{2} \mathrm{Te}, \mathrm{PhTeH}$ and PhTeNa. They offer some advantages over conventional reagents such as milder reaction conditions, better regiose- lectivity, in situ preparation of the reducing reagent, sometimes in catalytic conditions, and the recovery of tellurium in the elemental form or as diphenyl ditelluride.

\section{Reduction of carbonyl compounds}

Aldehydes and ketones can be reduced to the corresponding primary and secondary alcohols by $\mathrm{H}_{2} \mathrm{Te}$ and $\mathrm{PhTeH}$. The former is prepared by in situ hydrolysis of $\mathrm{Al}_{2} \mathrm{Te}_{3}$ and the latter by treatment of PhTeLi with $\mathrm{CF}_{3} \mathrm{CO}_{2} \mathrm{H}$ or methanolysis of $\mathrm{PhTeSiMe}_{3}{ }^{2-4}$. An additional method employs the $\mathrm{Bu}_{2} \mathrm{Te} / \mathrm{TiCl}_{4}$ system to generate $\mathrm{Ti}$ (III) species, which is the actual reducing agent ${ }^{5}$.

Selective reduction of the $\mathrm{C}=\mathrm{C}$ bond of $\alpha, \beta$-conjugated carbonyl compounds (aldehydes, ketones, esters, acids and amides) is achieved by treatment with $\mathrm{H}_{2} \mathrm{Te},{ }^{2} \mathrm{PhTeH}^{3,4}$ and NaHTe. ${ }^{3,6}$ The latter is prepared by treatment of elemental tellurium with $\mathrm{NaBH}_{4}$ in ethanol under controlled acidification with acetic acid.

\section{Reduction of conjugated aryl alkenes and alkynes}

$\mathrm{C}=\mathrm{C}$ and $\mathrm{C} \equiv \mathrm{C}$ bonds conjugated to aromatic groups are reduced to the corresponding saturated bonds by treatment with $\mathrm{PhTeH}^{3,4}$ or $\mathrm{NaHTe}^{3}$.

\section{Reduction of nitro compounds and other nitrogenated derivatives}

Nitroarenes give rise to different nitrogen compounds such as anilines ${ }^{2-5,7}$, azo $^{8}$ and azoxy ${ }^{7 \mathrm{~d}, 8 \mathrm{~b}}$ compounds and aryl hydroxylamines ${ }^{9}$ depending on the reducing agent and experimental conditions, while imines ${ }^{3,10}$ and enamines ${ }^{10 \mathrm{a}}$ 
are reduced to the corresponding amines by $\mathrm{H}_{2} \mathrm{Te}$, NaHTe and $\mathrm{PhTeH}$. An interesting and useful application is the one-step reductive alkylation of amines with carbonyl compounds ${ }^{10 \mathrm{a}, 11}$ (Eq. 1).

$$
\left.\underset{\mathrm{R}^{1}}{\mathrm{R}}\right\rangle=\mathrm{O}+\mathrm{R}^{2} \mathrm{NH}_{2} \underset{\mathrm{NaHTe}}{\stackrel{\mathrm{H}_{2} \mathrm{Te} \text { or }}{\longrightarrow}} \stackrel{\mathrm{R}}{\mathrm{R}} \succ-\mathrm{NHR}^{2}
$$

\section{Reduction of oxiranes}

Oxiranes can either be directly deoxygenated to alkenes by $(\mathrm{EtO})_{2} \mathrm{P}(\mathrm{O}) \mathrm{TeM}(\mathrm{M}=\mathrm{Na}, \mathrm{Li})^{12}$ in a stereoselective manner or via a two-step methodology, by reduction with NaHTe to a telluro alcohol (1), then a tosylation-elimination sequence furnishes an unstable epitelluride intermediate (2) which easily detellurates to an alkene ${ }^{13}$. Telluro alcohol (1) can also undergo reductive detelluration with nickel boride affording the corresponding alcohol, which in turn can be further oxidized to ketones ${ }^{13}$ (Scheme 1).

$\alpha, \beta$-Epoxyketones are reduced to the corresponding $\beta$-hydroxy ketones by $\mathrm{NaHTe}^{14}$. Epoxides bearing leaving groups in a suitable position are converted to allylic alcohols via formation of an epitelluride intermediate ${ }^{15}$. This methodology, combined with the Sharpless kinetic resolution of secondary allylic alcohols, provides a useful procedure for the conversion of racemic alcohols to pure single enantiomers $^{16}$ (Scheme 2).

\section{Debromination of vicinal dibromides}

This reaction proceeds via a typical anti-E $\mathrm{E}_{2}$ elimination by usage of reagents such as diaryl tellurides ${ }^{17 \mathrm{a}}$ and ditellurides $^{17 \mathrm{~b}}, \mathrm{NaHTe}^{17 \mathrm{c}}, \mathrm{Na}_{2} \mathrm{Te}^{17 \mathrm{~d}}$, (EtO) ${ }_{2} \mathrm{P}(\mathrm{O}) \mathrm{TeNa}^{17 \mathrm{e}}$, 2$\mathrm{ThTeNa}^{17 \mathrm{f}}$ and $\left(\mathrm{Ph}_{3} \mathrm{Sn}\right)_{2} \mathrm{Te}^{17 \mathrm{~g}}$. The advantages over the conventional methods are milder experimental conditions, higher yields, lack of side reactions and inertness of many functional groups towards the tellurium reagents. Several procedures can also be carried out using catalytic quantites of tellurium compound in the presence of a suitable reducing reagent, for instance potassium metabisulfite, for the regeneration of tellurium reagent ${ }^{17 \mathrm{~h}}$ (Scheme 3$)$.

\section{Reductive cleavage of carbon-heteroatom bonds}

Several tellurium reagents promote the title reductive cleavage on $\alpha$-halo ketones, whereas thienyl tellurolate can

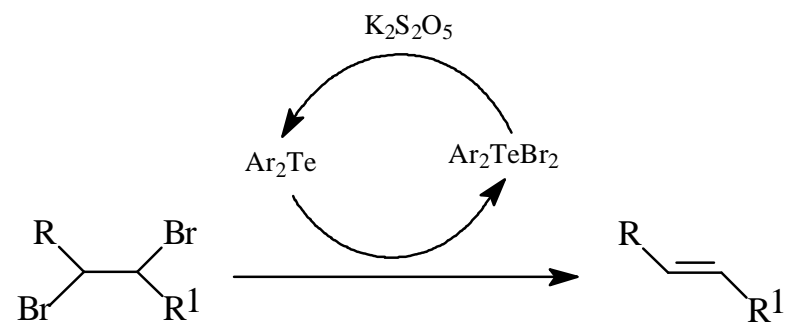

Scheme 3.

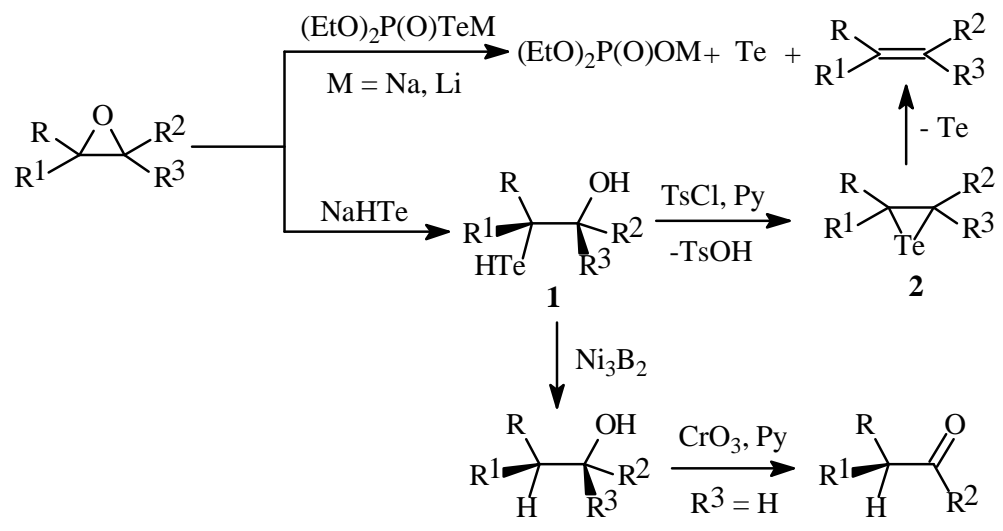

Scheme 1 .

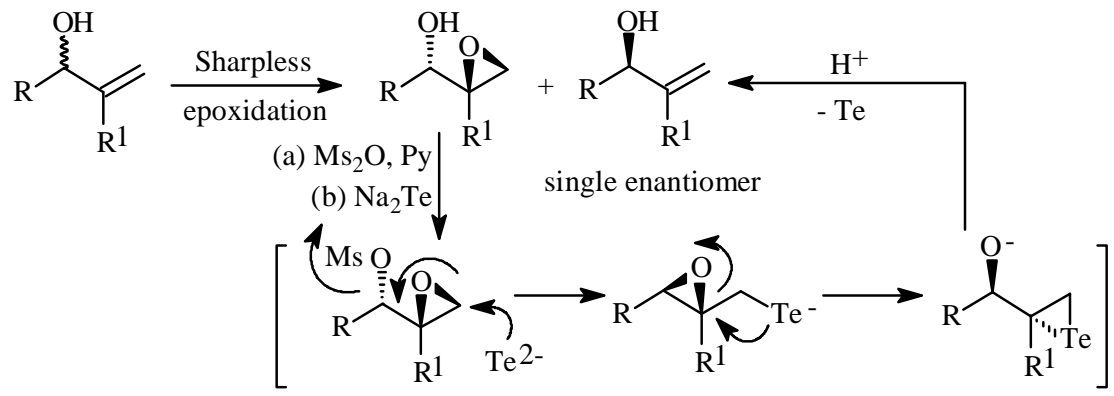

Scheme 2. 
also remove other heteroatom substituted leaving groups ${ }^{18}$ (Eq. 2).<smiles>[R]C(=O)C([R])([R])[X]</smiles>

$$
\begin{aligned}
\mathrm{X}= & \mathrm{Cl}, \mathrm{Br}, \mathrm{I} ;[\text { Red. }]=\mathrm{NaHTe},(\mathrm{EtO})_{2} \mathrm{P}(\mathrm{O}) \mathrm{TeNa}, \\
& \text { 2-ThTeLi }(\mathrm{Na}),\left(\mathrm{Ph}_{3} \mathrm{Sn}\right)_{2} \mathrm{Te} / \mathrm{KF} \\
\mathrm{X}= & \mathrm{OAc}, \mathrm{OMs}, \mathrm{SPh} ;[\text { Red. }]=2-\mathrm{ThTeLi}(\mathrm{Na})
\end{aligned}
$$

\section{Tellurium Promoted Formation of Anionic Species and Reaction with Electrophiles}

Nucleophilic attack of $\mathrm{Na}_{2} \mathrm{Te}$ at the halogen on $\alpha$-halo esters or nitriles leads to the corresponding carbanions which react with aldehydes giving $\alpha, \beta$-unsaturated compounds according to Reformatsky-type reactions ${ }^{19}$. The same tellurium reagent undergoes reaction with $\mathrm{Ph}_{2} \mathrm{~S}_{2}$ or $\mathrm{ArSO}_{2} \mathrm{Cl}$ affording thiolate and sulfinate anions through an electron transfer from the telluride ion. Further in situ reaction with $\alpha$-halo carbonyl compounds or alkyl halides leads to $\alpha$-thio carbonyl compounds and sulfones ${ }^{20}$ (Scheme 4).

$\mathrm{Bu}_{2} \mathrm{Te}$ promotes in situ generation of triphenyl methylene phosphorane from the parent phosphonium iodide for further Wittig methylenation reactions. The peculiarity of this methodology is the formation of phosphorane in neutral conditions ${ }^{21}$ (Scheme 5).

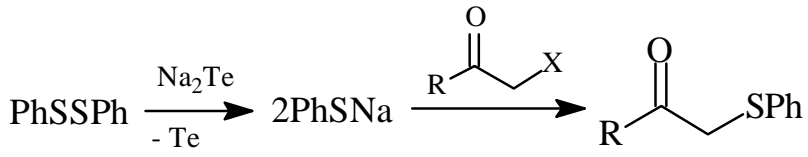

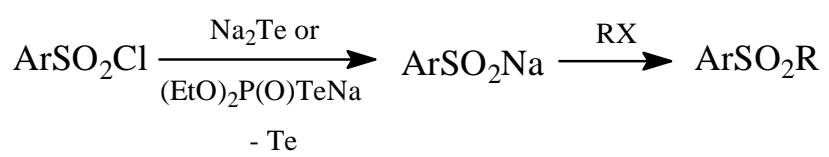

Scheme 4.

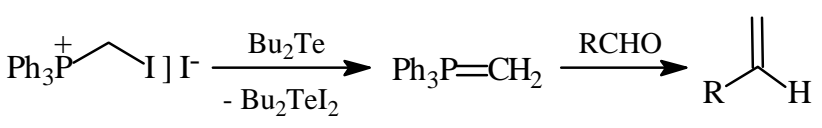

Scheme 5.

\section{Deprotection of Organic Functionalities}

Anionic tellurium species offer great possibilities for the regeneration of protected functional groups, the reactions proceeding under mild conditions in non-hydrolytic media. Carboxylic acids protected as alkyl or benzyl esters $^{22 \mathrm{a}}$, as well as phenacyl ${ }^{22 \mathrm{c}}$, allyl ${ }^{2 \mathrm{~d}}$ and $\beta$-halo ethyl carboxylates ${ }^{22 b, e, f}$ can be regenerated by $\mathrm{NaHTe}, \mathrm{Na}_{2} \mathrm{Te}$ and $\mathrm{Na}_{2} \mathrm{Te}_{2}$. Phenols can be regenerated from aryl carboxylates $^{23 \mathrm{a}}$, halo acetates ${ }^{22 \mathrm{e}}$ or carbonates ${ }^{23 \mathrm{~b}}$ by NaHTe and from phenyl allyl ethers ${ }^{22 \mathrm{~d}}$ by $\mathrm{Na}_{2} \mathrm{Te}$. Amines protected as trichloro- $t$-butyl carbamates can be regenerated by 2 $\mathrm{ThTeNa}^{24}$ (Scheme 6).

\section{Oxidation}

$\mathrm{An}_{2} \mathrm{TeO}$ is an easily prepared, stable crystalline compound which has been successfully employed as a mild and selective oxidizing reagent, with the advantage of possible regeneration from the corresponding telluride after the oxidative process. $(\mathrm{ArTeO})_{2} \mathrm{O}$ has recently been introduced as an oxidizing reagent, similarly to the former oxidant. Typical oxidations $\mathrm{s}^{25}$ are: thiols to disulfides, hidroquinones to quinones, diols and benzyl alcohols to aldehydes, acyl hydrazines to acyl hydrazides, $\mathrm{N}$-phenyl hydroxylamine to nitrosobenzene, benzophenone hydrazone to diphenyl diazomethane and phenyl isothiocyanate to diphenylurea. One important transformation is the oxidation of thio and seleno carbonyl compounds to the oxo-analogues. These oxidations can also be accomplished by a catalytic procedure (Scheme 7).

By treatment with $(\mathrm{PhTeO})_{2} \mathrm{O}$ in boiling $\mathrm{AcOH}$ under sulfuric acid catalysis, alkenes give rise to syn-diacetoxylated products ${ }^{26}$. Other methodology employs $\mathrm{TeO}_{2} / \mathrm{LiBr}$ or $\mathrm{TeCl}_{4} / \mathrm{LiOAc}$ in $\mathrm{AcOH}$. Aryl alkenes can also be dimethoxylated by treatment with $\mathrm{Ph}_{2} \mathrm{Te}_{2}$ and $t$-butyl peroxide in $\mathrm{MeOH}$ and sulfuric acid $^{27}$.

\section{Telluro Cyclofunctionalization}

Addition of an electrophilic tellurium reagent, for instance $\mathrm{ArTeCl}_{3}$, to alkenes $\mathrm{C}=\mathrm{C}$ bond bearing a nucleophilic moiety at a suitable position, followed by intramolecular trapping of the telluronium intermediate furnishes cyclic structures where the tellurium moiety lies outside the newly ring. Such reactions are known as tellurocyclofunctionalization and they can be either lactonization $^{28}$ or etherification ${ }^{29}$ (Scheme 8).

$$
\text { (2-ThTe) })
$$

Scheme 6. 
Other useful reagents for these cyclizations are: $\mathrm{PhTeOSO}_{2} \mathrm{C}_{6} \mathrm{H}_{4} \mathrm{NO}_{2}-4^{30 \mathrm{a}}$ for lactonizations and etherifications, and $\mathrm{ArTe}(\mathrm{O}) \mathrm{OAc}^{30 \mathrm{~b}}, \mathrm{TeO}_{2} / \mathrm{AcOH} / \mathrm{LiCl}^{30 \mathrm{c}}$ and $\mathrm{TeO}_{2} / \mathrm{HCl} / \mathrm{MeOH}^{30 \mathrm{~d}}$ for etherifications. Similar reactions are also well known with the selenium analogs. Reductive removal of the tellurium moiety from the cyclic products can be achieved by further reaction with $\mathrm{Bu}_{3} \mathrm{SnH}^{31}$.

\section{Replacement of Tellurium Moiety with Other Atoms}

\section{Replacement by halogens: halogenodetelluration}

$\mathrm{ArTeCl}_{3}$ and $\mathrm{Ar}_{2} \mathrm{TeCl}_{2}$ bearing a para-electron-donating group on the aromatic ring undergo Te/I exchange in the presence of fluoride anions through an electrophilic mechanism $^{32 a}$. A similar reaction has also been carried out on vinylic tellurium trichlorides $(3)$ with $I_{2}$ or NBS. Since compounds $\mathbf{3}$ are easily prepared from phenylacetylenes,

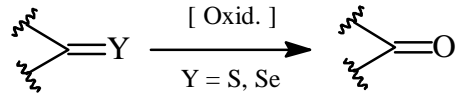

$$
\begin{aligned}
& \text { [Oxid. }=(\mathrm{MeO} \longrightarrow)_{2} \mathrm{TeO} ;(\operatorname{ArTeO})_{2} \mathrm{O}
\end{aligned}
$$

Catalytic process :

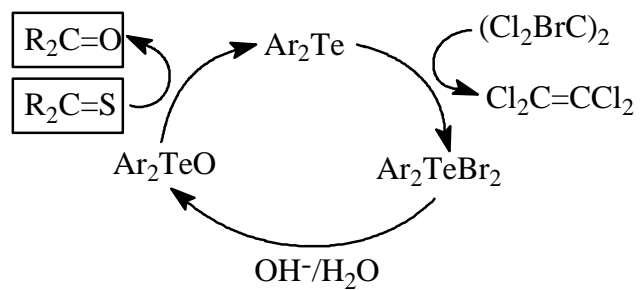

Scheme 7.
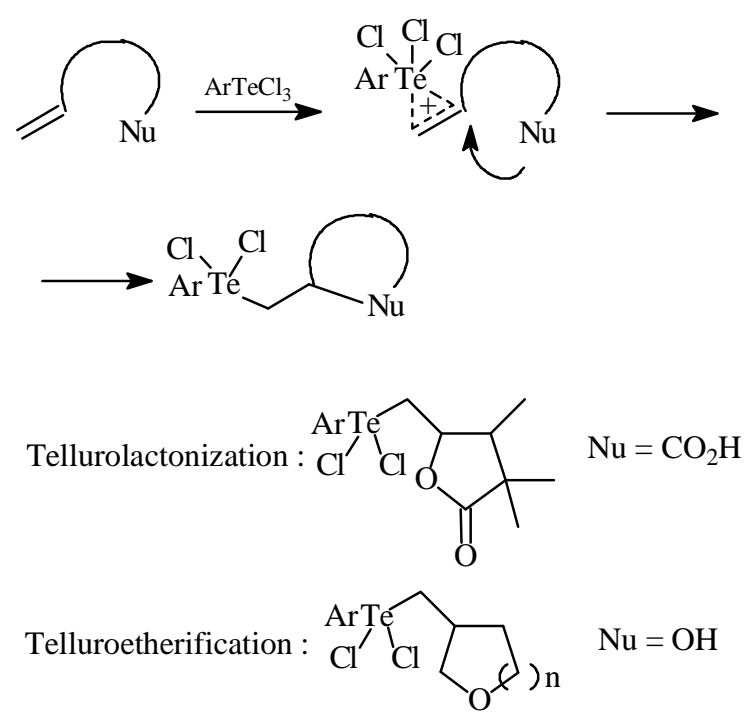

Scheme 8. this two-step sequence offers a simple methodology for the syn-iodo- or bromo-chlorination of alkynes ${ }^{32 \mathrm{~b}}$ (Scheme 9).

Ipso-substitution (or $\alpha$-elimination) on tellurium (IV) halides, i.e. selective transfer of halogen from tellurium to the carbon moiety ${ }^{33}$, can be performed on suitable substrates such as $\mathrm{RTeCl}_{3}$ ( $\mathrm{R}=$ alkyl, vinyl, aryl), $\mathrm{Ar}_{2} \mathrm{TeCl}_{2}$ and $\mathrm{PhTe}(\mathrm{Br})_{2} \mathrm{R}(\mathrm{R}=$ alkyl) by oxidative, photolytic or pyrolytic procedures depending on the tellurium substrates. The latter procedure is useful for homologation of alkyl halides (Scheme 10). Other halogenodetellurations can also be accomplished by reaction of $\alpha$-dichloro telluro ketones ${ }^{34 \mathrm{a}}$ and acetylenic tellurides ${ }^{34 b}$ with halogens.

\section{Replacement by alkoxy group}

Alkyl phenyl telluroxides are easily obtained by oxidation of parent tellurides with mCPBA or by alkaline hydrolysis of the corresponding dibromides. Treatment of telluroxides with excess mCPBA or $\mathrm{CF}_{3} \mathrm{CO}_{3} \mathrm{H}$ in alcohols leads to detelluration and formation of alkyl ethers. Alkyl phenyl tellurones, obtained by oxidation of telluroxides with $\mathrm{NaIO}_{4}$ give similar results under the same conditions $^{35 a}$ (Scheme 11).

Phenyl migration ${ }^{35 a}$ has been reported on structures bearing a phenyl group vicinal to the tellurium moiety. This

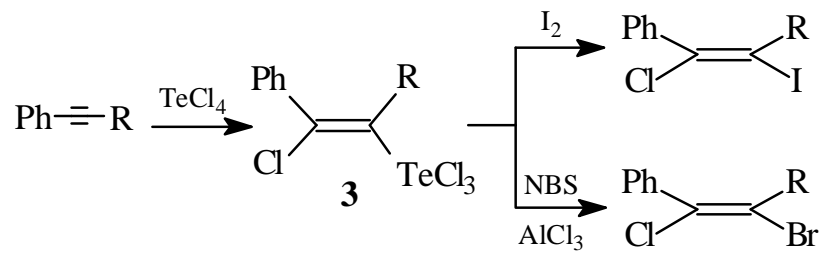

Scheme 9.

Ipso-substitution

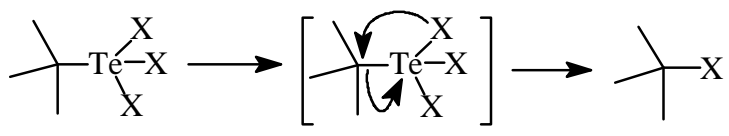

Homologation of alkyl halides

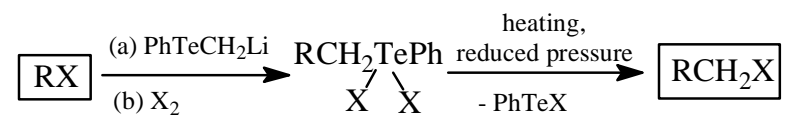

Scheme 10.

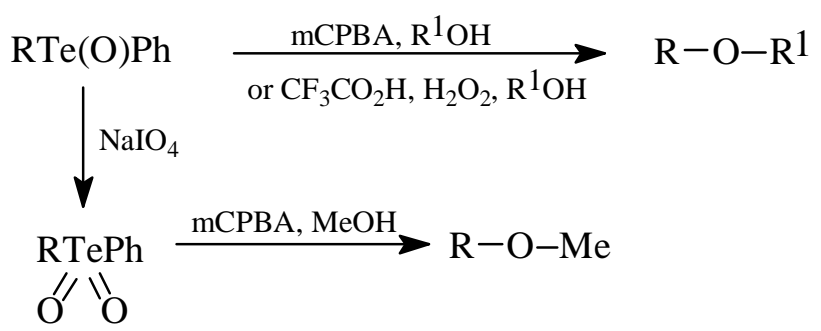

Scheme 11. 
methodology has been used to prepare $\alpha$-aryl propanoic acids, which are important anti-inflamatory pharmaceuticals, from aryl ethyl ketones ${ }^{35 b}$. Ring contractions of 1-tellurium-2-alkoxy-cyclohexanes has also been accomplished under similar detellurative methoxylation conditions $^{35 a}$.

\section{Replacement by hydrogen}

Phenyl alkyl tellurides undergo mild reductions with $\mathrm{Ph}_{3} \mathrm{SnH}$ furnishing the corresponding alkanes ${ }^{36}$. Since the starting tellurides are easily prepared from nucleophilic substitution of alkyl halides with tellurolate anions, the overall sequence offers a mild reduction methodology for alkyl halides.

\section{Detelluration with C-C Bond Formation}

\section{Detellurative coupling reaction}

The extrusion of tellurium from organotellurium compounds leading to coupled products can be achieved by Raney- $\mathrm{Ni}^{37 \mathrm{a}, \mathrm{b}}, \mathrm{Pd}(0)^{37 \mathrm{c}}$ or $\mathrm{Li}_{2} \mathrm{PdCl}_{4}{ }^{37 \mathrm{~d}}$ (Scheme 12).

\section{Detellurative cross-coupling reaction}

Alkenes bearing electron-withdrawing groups undergo arylation or vinylation by treatment with $\mathrm{Ar}_{2} \mathrm{TeCl}_{2}$, $\mathrm{ArTeCl}_{3}, \mathrm{Ar}_{2} \mathrm{Te}$ or vinylic tellurides ${ }^{38}$ in the presence of $\mathrm{PdCl}_{2}$ or $\mathrm{Pd}(\mathrm{OAc})_{2}$ (Scheme 13). These cross-coupling reactions can be carried out using catalytic amounts of Pd (II) salts in the presence of a suitable oxidant such as $t$ - $\mathrm{BuOOH}, \mathrm{CuCl}_{2}$ or $\mathrm{AgOAc}$. Under Ni (II) or Co (II) phosphine complex catalysis, some organotellurides react with Grignard reagents furnishing both cross-coupled and homo-coupled products ${ }^{39}$ (Scheme 13).

\section{Detellurative carbonylation}

Pd (II) also promotes detellurative carbonylations ${ }^{40}$ of alkyl, vinyl, alkynyl and phenyl tellurides with $\mathrm{CO} / \mathrm{MeOH} / \mathrm{Et}_{3} \mathrm{~N}$ giving methyl carboxylates. While performed in the presence of $\mathrm{CuCl}_{2}$ as oxidant, only catalytical amount of Pd (II) is needed. The same methodology is also suitable to prepare substituted butenolides starting from hydroxy vinyl tellurides (Scheme 14).

\section{Vinylic Tellurides}

Vinylic tellurides are important compounds due to their peculiar behaviour as synthons and intermediates. The general preparative procedure is the addition of organyl tellurolates, obtained from reduction of the corresponding ditellurides with $\mathrm{NaBH}_{4}$, to acetylenes. This addition reaction is highly stereoselective, occurring exclusively in anti mode giving $Z$ adducts ${ }^{41}$ (Scheme 15), which is in sharp contrast to the well known hydrostannylation ${ }^{42 a}$, hydrozirconation $^{42 \mathrm{~b}}$ and hydroalumination ${ }^{42 \mathrm{c}}$ of acetylenes, characterized by syn addition modes furnishing $E$ products. ${ }^{42}$ Z-Divinyl tellurides, in turn, are prepared by addition of $\mathrm{Na}_{2} \mathrm{Te}$ to activated terminal alkynes ${ }^{41 \mathrm{~d}}$ (Scheme 15).

\section{Detellurative cross-coupling reaction with organocuprates}

Substitution of tellurium moiety on vinylic tellurides with retention of the $\mathrm{C}=\mathrm{C}$ bond geometry has been per-

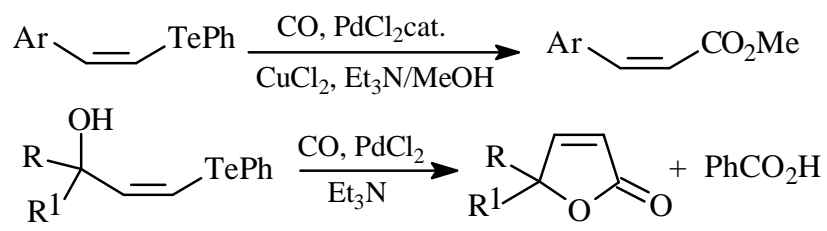

Scheme 14.

$$
\begin{aligned}
& \mathrm{Ar}_{2} \mathrm{TeCl}_{2} \text { or } \mathrm{ArTeCl}_{3} \underset{\text { heat }}{\stackrel{\mathrm{Ra}-\mathrm{Ni}}{\longrightarrow}} \mathrm{Ar}-\mathrm{Ar} \\
& \mathrm{RTeR}^{1} \underset{\text { heat }}{\stackrel{\mathrm{Pd}(0)}{\longrightarrow}} \mathrm{R}-\mathrm{R}^{1} \\
& (\mathrm{Ph}=-)_{2} \mathrm{Te} \text { or 2eq. } \mathrm{Ph}=-\mathrm{TePh} \stackrel{\mathrm{Li}_{2} \mathrm{PdCl}_{4}}{\longrightarrow} \mathrm{Ph} \stackrel{\sim}{\longrightarrow} \mathrm{Ph}
\end{aligned}
$$

Scheme 12.

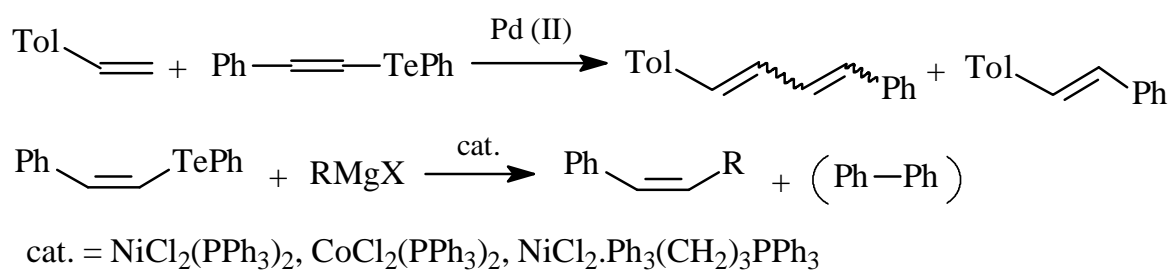

Scheme 13. 


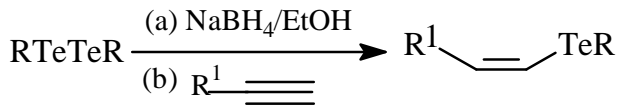

$$
\begin{aligned}
& \mathrm{R}^{1}=\text { alkyl, aryl, } \mathrm{CO}_{2} \mathrm{Et} \text {, vinyl, alkynyl } \\
& \mathrm{Te} \underset{\mathrm{EtOH} / \mathrm{H}_{2} \mathrm{O} / \mathrm{THF}}{\stackrel{\mathrm{NaBH}_{4}, \mathrm{NaOH}}{\longrightarrow}} \mathrm{Na}_{2} \mathrm{Te} \stackrel{\mathrm{R} \longrightarrow}{\longrightarrow} \underset{\mathrm{T}}{\longrightarrow} \rightleftharpoons
\end{aligned}
$$

Scheme 15.

formed with different types of organocuprates. Lithium diorganocuprates ${ }^{43 a}$ furnish cross-coupled products with vinylic tellurides (Eq. 3, Scheme 16), and upon reaction with 1,2-ditelluro substituted alkenes, only the terminal tellurium moiety is detellurated. Lower order lithium or magnesium cyanocuprates ${ }^{43 b}$ (Eq. 4, Scheme 16) as well as higher order mixed lithium-magnesium, dimagnesium ${ }^{43 \mathrm{c}}$ and zinc cyanocuprates ${ }^{43 d}$ (Eqs. 5 and 6, Scheme 16) also promote similar reactions. Interestingly, the latter reagents led to complete inversion of the $\mathrm{C}=\mathrm{C}$ bond geometry in the coupled products.

$$
\begin{aligned}
& \mathrm{Ph} \underset{ }{\mathrm{TePh}} \stackrel{\mathrm{Me}_{2} \mathrm{CuLi}}{\longrightarrow} \mathrm{Ph} \underset{ }{\longrightarrow}{ }^{\mathrm{Me}} \\
& \mathrm{R}_{\mathrm{TeR}} \stackrel{\mathrm{R}^{2} \mathrm{Cu}(\mathrm{CN}) \mathrm{Li}}{\underset{\text { or } \mathrm{R}^{2} \mathrm{Cu}(\mathrm{CN}) \mathrm{MgBr}}{\longrightarrow}} \mathrm{R} \rightleftharpoons \mathrm{R}^{2} \\
& \mathrm{R}=\text { alkyl, } \mathrm{Ph} \text {, vinyl, alkynyl, } \mathrm{CO}_{2} \mathrm{Et} ; \mathrm{R}^{1}=n-\mathrm{Bu}, \mathrm{Ar} \\
& \mathrm{R}^{2}=\text { prim, sec, tert-alkyl } \\
& \mathrm{Ph} \rightleftharpoons{ }_{\mathrm{TeR}} \underset{{\text { or } \mathrm{R}^{1}{ }_{2} \mathrm{Cu}(\mathrm{CN})(\mathrm{MgBr})_{2}}_{\mathrm{R}^{1} \mathrm{Cu}(\mathrm{CN})(\mathrm{MgBr}) \mathrm{Li}}^{\longrightarrow}}{\longrightarrow} \mathrm{Ph}_{\mathrm{R}} \\
& \mathrm{R}=\text { alkyl, vinyl, } \mathrm{Ar} ; \mathrm{R}_{2}=n-\mathrm{Bu}, n-\mathrm{Bu}(2-\mathrm{Th}) \\
& \mathrm{RTe} \smile \mathrm{COCF}_{3} \stackrel{\mathrm{R}_{2}{ }_{2} \mathrm{Cu}(\mathrm{CN})(\mathrm{ZnCl})_{2}}{\longrightarrow} \mathrm{R}^{1}=\mathrm{COCF}_{3}
\end{aligned}
$$

Scheme 16.

\section{Olefin Synthesis}

Although not so well known as the familiar selenoxide syn-elimination, the corresponding telluroxide elimination $^{44}$ has recently gained more attention among the olefin synthesis methodologies. The starting telluroxides are prepared by hydrolysis of parent dibromides or by oxidation of tellurides with mCPBA. The elimination reaction, which is preferential towards the less substituted carbon, can occur either at room temperature or upon heating over $200{ }^{\circ} \mathrm{C}$ depending on the starting telluroxide. Combination of this methodology with the easy obtention of alkyl phenyl tellurides from the corresponding halides provides a straightforward route to the dehydrobromination of alkyl bromides. Moreover, this methodology can provide vinyl ethers, allyl ethers and alcohols when combined with the alkoxy telluration of alkenes, or with the oxirane ring opening by tellurolates (Scheme 17).

Some noteworthy details have been reported in respect to the elimination reaction, they are: addition of $\mathrm{Et}_{3} \mathrm{~N}$ increasing the yields of elimination products, pyridinyl tellurium $^{45 a}$ moiety as a better leaving group than phenyl tellurium moiety, and alkyl ferrocenyl tellurides ${ }^{45}$ being successfully submitted to elimination sequences in the presence of $\mathrm{Et}_{3} \mathrm{~N}$ or tetracyano ethylene.

Allylic telluroxides undergo [2,3]-sigmatropic rearrangements ${ }^{46}$ furnishing allylic alcohols after hydrolysis. The same sequence when performed on chiral allylic ferrocenyl tellurides shows evidence of chirality transfer to the allylic alcohol as the rearranged product (Scheme 18).

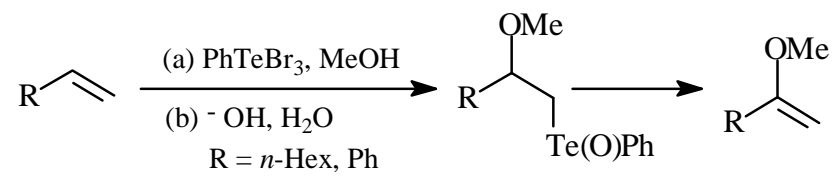
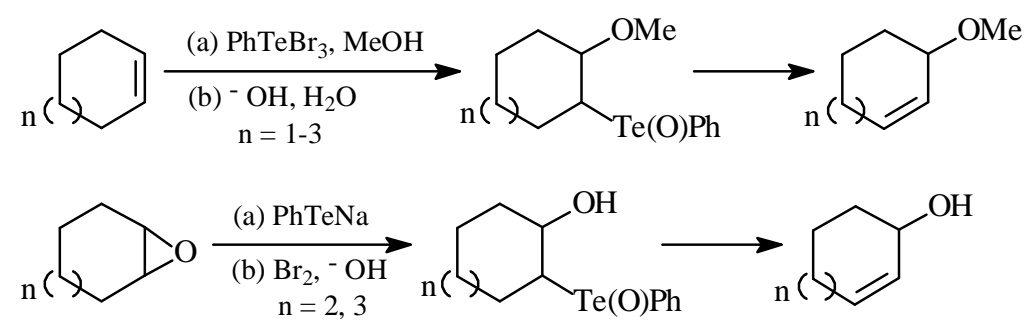

Scheme 17. 


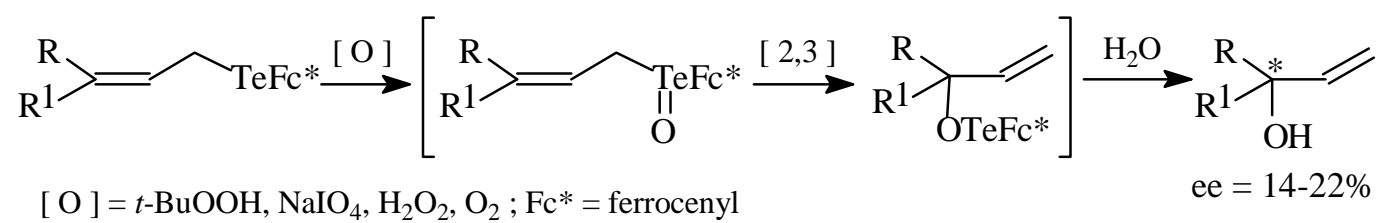

Scheme 18.

Olefin synthesis via tellurium compounds can also be accomplished by usage of telluronium ylides. They are prepared by treatment of telluronium salts bearing electronwithdrawing groups with bases and can be submitted to Wittig-type olefination reactions with a variety of carbonyl compounds $^{47}$ (Scheme 19). A high $E$ stereoselectivity is observed in in reactions with aldehydes. These results are especially noteworthy when compared to those from stabilized sulfonium ylides which are non reactive towards carbonyl compounds.

On the other hand, semi- and non-stabilized telluronium ylides, for instance di-i-butyl telluronium allylide, diphenyl telluronium methylide and di-i-butyl telluronium trimethylsilyl propynylide, react with aldehydes and ketones giving epoxides ${ }^{48}$, showing similar chemical behaviour to non-stabilized sulfonium and selenonium ylides.

\section{Transmetalation Reaction}

\section{Te/Li exchange - organolithium reagents}

By treatment of diorganyl tellurides with alkyllithiums, a $\mathrm{Te} / \mathrm{Li}$ exchange reaction takes place generating the most stable organolithium derivative $e^{41 e, 49}$. This transmetalation is very useful for the preparation of lithium reagents which cannot be achieved by conventional methods such as allyl, benzyl, propargyl, acyl, aroyl and heteroatom substituted methyllithiums. The Te/Li exchange on $Z$-vinylic tellurides occurs with retention of the original geometry of the $\mathrm{C}=\mathrm{C}$ bond providing a useful methodology for preparation of $Z$-vinyllithiums. The resulting new organolithiums can be trapped with a variety of different electrophiles, as shown in the following representative examples (Scheme 20).

Stabilized telluronium ylides

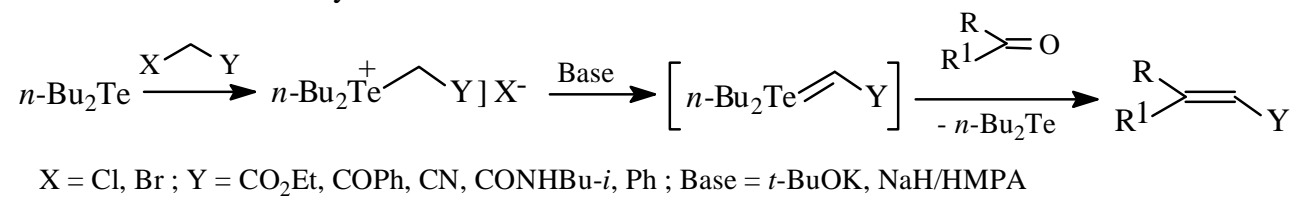

Scheme 19.

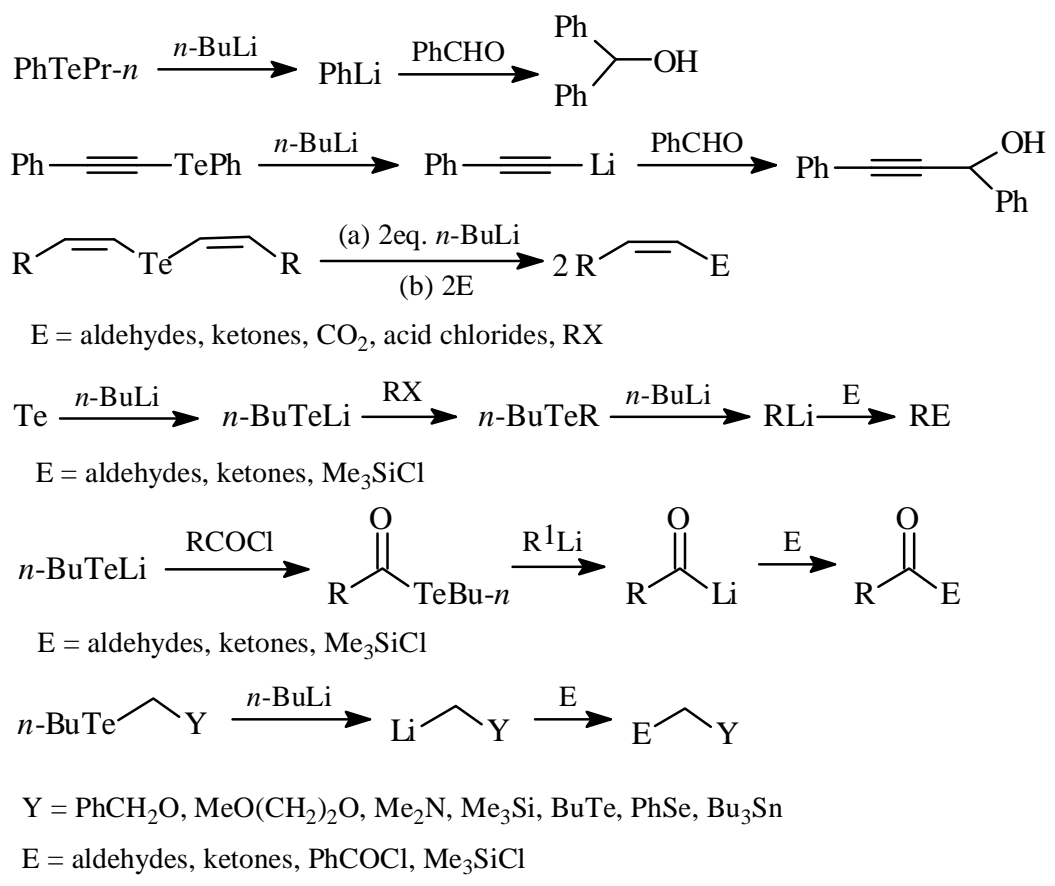

Scheme 20. 


\section{Te/Na, K, $\mathrm{Mg}, \mathrm{Ca}$, Zn exchange}

Transmetalations with $\mathrm{Na}, \mathrm{K}, \mathrm{Mg}$ and $\mathrm{Ca}$ were performed on alkyl, alkenyl, aryl, allyl and benzyl tellurides, ${ }^{50}$ while $\mathrm{Te} / \mathrm{Zn}$ exchange reaction ${ }^{51}$ followed by coupling with aryl iodide was achieved under palladium catalysis (Scheme 21).

\section{Te/Cu exchange - organocopper reagents}

The most promising synthetic application of $Z$-vinylic tellurides is their transmetalation with higher order cyanocuprates. The counter-ion in the cuprate plays as important role in this reaction. Instead of a detellurative cross-coupling reaction as observed with lithium-magnesium and di-magnesium derivatives, the dilithium cyanocuprate promotes $\mathrm{Te} / \mathrm{Cu}$ exchange giving higher order vinylic cyanocuprates with retention of the original $\mathrm{C}=\mathrm{C}$ bond geometry. The resulting $Z$-vinylic cuprates readily undergo conjugate addition to $\alpha, \beta$-unsaturated ketones ${ }^{52 \mathrm{a}, \mathrm{b}}$, epoxide ope- $\operatorname{ning}^{52 \mathrm{~b}}$ and coupling reaction with bromo alkynes in the presence of $\mathrm{ZnCl}_{2}{ }^{52 \mathrm{c}}$ (Scheme 22).

There are some special higher order cyanocuprates such as dimethyl, (2-thienyl, butyl) and (imidazoyl, butyl) dilithium cyanocuprates which carry the so-called "dummy ligands" that are non-transferable from the cuprate, therefore avoiding formation of undesired addition by-products.

\section{Radical Reaction}

By treatment with $\mathrm{Li}_{2} \mathrm{Te}$, allylic halides furnishes 1,5dienes ${ }^{53}$ via a coupling reaction of the corresponding allylic radicals. Upon irradiation of a mixture containing the acetyl derivative of N-hydroxy-2-thiopyridone (4), alkyl anisyl telluride and an electrophilic olefin, a radical chain mechanism $^{54}$ takes place, which is useful in intramolecular cyclizations affording six-membered rings (Scheme 23). The same mixture is also useful in tellurium mediated addition of carbohydrates to olefins.

$$
\begin{aligned}
& \mathrm{RTeR}^{1} \stackrel{\mathrm{R}^{2} \mathrm{M}}{\longrightarrow}\left[\mathrm{R}^{1} \mathrm{M}\right] \stackrel{\mathrm{E}}{\longrightarrow} \mathrm{R}^{1} \mathrm{E} \\
& \mathrm{R}=n \text {-Bu, } \mathrm{Ph} ; \mathrm{R}^{1}=\text { alkyl, alkenyl, allyl, bn, } \mathrm{Ar} \\
& \mathrm{M}=\mathrm{Na}, \mathrm{K}, \mathrm{CaI}, \mathrm{MgCl} \\
& \mathrm{E}=\text { aldehydes, ketones }
\end{aligned}
$$

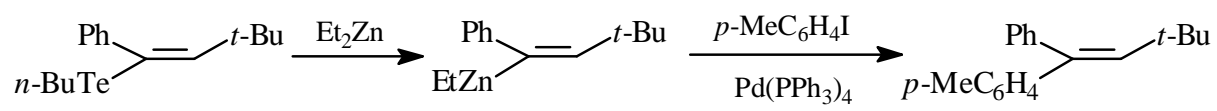

Scheme 21.
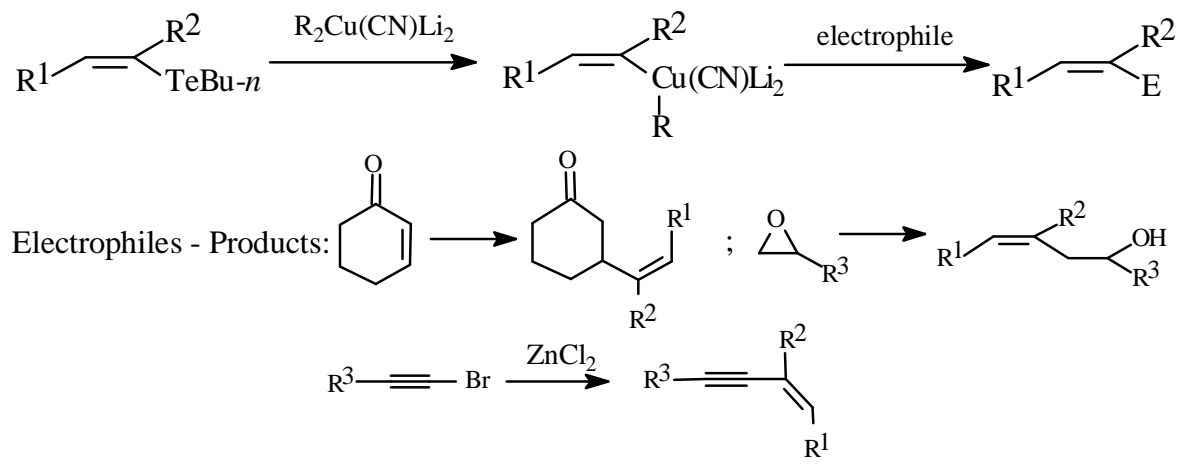

Scheme 22

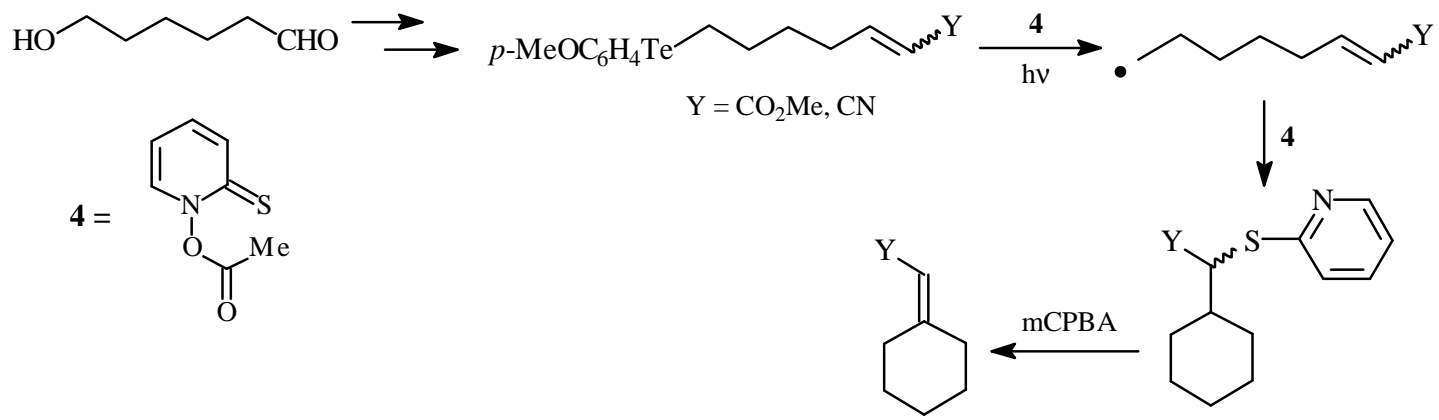

Scheme 23. 


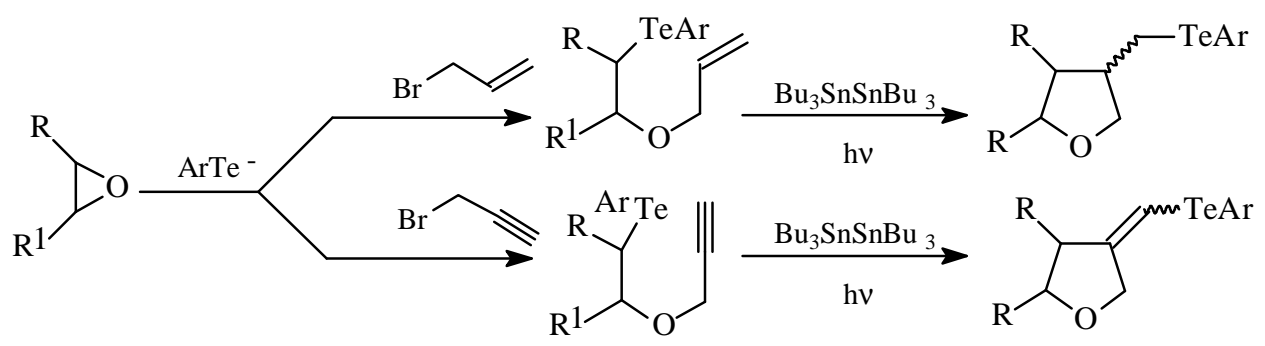

Scheme 24 .

Recently, telluro methyl and methylene substituted tetrahydrofurans ${ }^{55}$ were obtained from epoxides by combination of tellurolate promoted oxirane ring opening and radical cyclizations (Scheme 24).

\section{Acknowledgments}

The authors acknowledge financial support from FAPESP and CNPq.

\section{References}

1. (a) Rheinboldt, H. In Houben-Weyl Methoden der Organischen Chemie, Müller, E. Ed., $4^{\text {th }}$ Ed., vol. IX; G. Thieme; Stuttgart, 1955; (b) Irgolic, K.Y. In Houben-Weyl Methoden der Organischen Chemie, Müller, E. Ed., $4^{\text {th }}$ Ed., vol. E12b; G. Thieme; Stuttgart, 1990.

2. Kambe, N.; Kondo, K.; Morita, S.; Murai, S.; Sonoda, N. Angew. Chem. Int. Ed. Engl. 1980, 19, 1009.

3. Akiba, M.; Cava, M.P. Synth. Commun. 1984, 14, 1119.

4. Aso, Y.; Nishioka, T.; Osuka, M.; Nagakawa, K.; Sasaki, K.; Otsubo, T.; Ogura, F. Nippon Kagaku Kaishi 1987, 1490.

5. Suzuki, H.; Manabe, H.; Enokiya, R.; Hanazaki, Y. Chem. Lett. 1986, 1339.

6. (a) Ramasamy, K.; Kalyanasundaram, S.K.; Shanmungam, P. Synthesis 1978, 545; (b) Yamashita, M.; Kato, Y.; Suemitsu, R. Chem. Lett. 1980, 847; (c) Huang, X.; Zhang, H. Synth. Commun. 1989, 19, 97.

7. (a) Kambe, N.; Kondo, K.; Sonoda, N. Angew. Chem. Int. Ed. Engl. 1980, 19, 1009; (b) Suzuki, H.; Manabe, H.; Inouye, M. Chem. Lett. 1985, 1671; (c) Ohira, N.; Aso, Y.; Otsubo, T.; Ogura, F. Chem. Lett. 1964, 853; (d) Osuka, A.; Shimizu, H.; Suzuki, H. Chem. Lett. 1983, 1373; (e) Suzuki, H.; Hanazaki, Y. Chem. Lett. 1986, 549.

8. (a) Suzuki, H.; Manabe, H.; Kawaguchi, T.; Inouye, M. Bull. Chem. Soc. Jpn. 1987, 60, 771; (b) Ohe, K.; Uemura, S.; Sugita, N.; Masuda, H.; Taga, T. J. Org. Chem. 1989, 54, 4169.

9. Uchida, S.; Yanada, K.; Yamaguchi, H.; Meguri, H. Chem. Lett. 1983, 1069.

10. (a) Kambe, N.; Inagaki, T.; Miyoshi, N.; Ogawa, A.; Sonoda, N. Chem. Lett. 1987, 1275; (b) Barton,
D.H.R.; Fekih, A.; Lusinchi, X. Tetrahedron Lett. 1985, 26, 3693.

11. Yamashita, M.; Kadokura, M.; Suemitsu, R. Bull. Chem. Soc. Jpn. 1984, 57, 3359.

12. Clive, D.L.J.; Menchen, S.M. J. Org. Chem. 1980, 45, 2347.

13. Barton, D.H.R.; Fekih, A.; Lusinchi, X. Tetrahedron Lett. 1985, 26, 6197.

14. Osuka, A.; Takaoka, K.; Suzuki, H. Chem. Lett. 1984, 271.

15. Polson, G.; Dittmer, D.C. Tetrahedron Lett. 1986, 27 , 5579.

16. (a) Discordia, R.P.; Dittmer, D.C. J. Org. Chem. 1990, 55, 1414; (b) Dittmer, D.C.; Discordia, R.P.; Zhang, Y.; Murphy, C.K.; Kumar, A.; Pepito, A.S.; Wang, Y. J. Org. Chem. 1993, 58, 718.

17. (a) Moura Campos, M.; Petragnani, N. Tetrahedron Lett. 1960, 5; (b) Petragnani, N.; Moura Campos, M. Chem. Ber. 1961, 94, 1759; (c) Ramasamy, K.; Kalyanasundaram, S.K.; Shanmugam, P. Synthesis 1978, 311; (d) Suzuki, S.; Inouye, M. Chem. Lett. 1985, 225; (e) Huang, X.; Hou, Y.Q. Synth. Commun. 1988, 18, 2201; (f) Engman, L. Tetrahedron Lett. 1982, 23, 3601; (g) Li, C.J.; Harp, D.N. Tetrahedron Lett. 1990, 31, 6291; (h) Suzuki, H.; Kondo, A.; Osuka, A. Bull. Chem. Soc. Jpn. 1985, 58, 1335.

18. (a) Osuka, A.; Suzuki, H. Chem. Lett. 1983, 119; (b) Clive, D.L.J.; Beaulieu, P.L. J. Org. Chem. 1982, 47, 1124; (c) Engman, L.; Cava, M.P. J. Org. Chem. 1982, 47, 3946; (d) Li, C.J.; Harpp, D.N. Tetrahedron Lett. 1991, 32, 1545.

19. Suzuki, H.; Inouye, M. Chem. Lett. 1986, 403.

20. (a) Padmanabhan, S.; Ogawa, T.; Suzuki, H. Bull. Chem. Soc. Jpn. 1989, 62, 1358; (b) Suzuki, H.; Nishioka, Y.; Padmanabhan, S.; Ogawa, T. Chem. Lett. 1988, 727; (c) Huang, X.; Pi, J.H. Synth. Commun. 1990, 2291.

21.Li, S.W.; Huang, Y.Z.; Shi, L.L. Chem. Ber. 1990 , 123, 1441.

22. (a) Chen, J.; Zhou, X.J. Synthesis 1987, 586; (b) Synth. Commun. 1987, 17, 161; (c) Huang, Z.; Xie, L.; Huang, X. Synth. Commun. 1988, 18, 1167; (d) Shobana, N.; Shanmugam, P. Indian J. Chem. 1986, 25B, 658; (e) Suzuki, H.; Padmanabham, S.; Ogawa, T. 
Chem. Lett. 1989, 1017; (f) Huang, Z.; Zhou, X.J. Synthesis 1990, 633.

23. (a) Shobana, N.; Shanmugam, P. Indian J. Chem. 1985, 24B, 690; (b) Shobana, N.; Amirthavalli, M.; Deepa, V.; Shanmugam, P. Indian J. Chem. 1988, $27 B, 965$.

24. Lakshimikantham, M.V.; Jackson, Y.A.; Jones, R.Y.; O’Malley, C.J.; Ravichandran, K.; Cava, M.P. Tetrahedron Lett. 1986, 27, 4687.

25. (a) Ley, S.V.; Merholz, C.A.; Barton, D.H.R. Tetrahedron 1981, 37, 213; (b) Barton, D.H.R.; Finet, J.P.; Thomas, M. Tetrahedron 1986, 42, 2319; (c) Hu, N.X.; Aso, Y.; Otsubo, T.; Ogura, F. Tetrahedron Lett. 1986, 27, 6099.

26. (a) Kambe, N.; Tsukamoto, T.; Miyoshi, N.; Murai, S.; Sonoda, N. Chem. Lett. 1987, 269; (b) Uemura, S.; Ohe, K.; Fukuzawa, S.I.; Patil, S.R.; Sugita, N. J. Organomet. Chem. 1986, 316, 67; (c) Fukuzawa, S.I.; Irgolic, K.J.; O’Brien, D.H. Organometallics 1990, 9 , 3079 .

27. (a) Kambe, N.; Fujioka, T.; Ogawa, A.; Miyoshi, N.; Sonoda, N. Chem. Lett. 1987, 2077; (b) Phosphorus and Sulfur 1988, 38, 167.

28. (a) Moura Campos, M.; Petragnani, N. Chem. Ber. 1960, 93, 317; (b) Comasseto, J.V.; Petragnani, N. Synth. Commun. 1983, 13, 889.

29. Comasseto, J.V.; Ferraz, H.M.C.; Petragnani, N. Tetrahedron Lett. 1987, 28, 5611.

30. (a) Yoshida, M.; Suzuki, T.; Kamigata, N. J. Org. Chem. 1992, 57, 383; (b) Hu, N.X.; Aso, Y.; Otsubo, T.; Ogura, F. J. Org. Chem. 1989, 54, 4391; (c) Bergman, J.; Engman, L. J. Am. Chem. Soc. 1981, 103, 5196; (d) Engman, L. Organometallics 1989, 8, 1997.

31. Comasseto, J.V.; Ferraz, H.M.C.; Brandt, C.A.; Gaeta, K.K. Tetrahedron Lett. 1989, 30, 1209.

32. (a) Uemura, S.; Fukuzawa, S.I.; Wakasugi, M.; Okano, M. J. Organomet. Chem. 1981, 214, 319; (b) Uemura, S.; Miyoshi, H.; Okano, M. Chem. Lett. 1979, 1357.

33. (a) Uemura, S.; Fukuzawa, S.I. J. Organomet. Chem. 1984, 268, 223; (b) Chem. Lett. 1980, 943.

34. (a) Stefani, H.A.; Chieffi, A.; Comasseto, J.V. Organometallics 1991, 10, 1178; (b) Dabdoub, M.J.; Comasseto, J.V.; Barros, S.M.; Moussa, F. Synth. Commun. 1990, 20, 2181.

35. (a) Uemura, S.; Fukuzawa, S.I. J. Chem. Soc., Perkin Trans. I 1985, 471; (b) J. Chem. Soc., Perkin Trans. I 1986, 1983.

36. Clive, D.L.J.; Chittattu, G.J.; Farina, V.; Kiel, W.A.; Menchen, S.M.; Russell, C.G.; Singh, A.; Wong, C.K.; Curtis, N.J. J. Am. Chem. Soc. 1980, 102, 4438.

37. (a) Bergman, J. Tetrahedron 1972, 28, 3323; (b) Bergman, J.; Engman, L. Tetrahedron 1980, 36, 1275; (c) Barton, D.H.R.; Ozbalik, N.; Ramesh, M. Tetrahe- dron Lett. 1988, 29, 3533; (d) Uemura, S.; Takahashi, H.; Ohe, K. J. Organomet. Chem. 1992, 423, C9.

38. (a) Uemura, S.; Wakasugi, M.; Okano, M. J. Organomet. Chem. 1980, 194, 277; (b) Nishibayashi, Y.; Cho, C.S.; Uemura, S. J. Organomet. Chem. 1996, 507, 197.

39. Uemura, S.; Fukuzawa, S.H.; Patil, S.R. J. Organomet. Chem. 1983, 243, 9.

40. (a) Ohe, K.; Takahashi, H.; Uemura, S.; Sugita, N. J. Organomet. Chem. 1987, 326, 35; (b) J. Org. Chem. 1987, 52, 4859.

41. (a) Dabdoub, M.J.; Dabdoub, V.B.; Comasseto, J.V.; Petragnani, N. J. Organomet. Chem. 1986, 308, 211; (b) Ohe, K.; Takahashi, H.; Uemura, S.; Sugita, N. J. Org. Chem. 1987, 52, 4859; (c) Uemura, S.; Fukuzawa, S.I.; Patil, S.R. J. Organomet. Chem.1989, 243, 9; (d) Barros, S.M.; Dabdoub, M.J.; Dabdoub, V.M.; Comasseto, J.V. Organometallics 1989, 8, 1661; (e) Dabdoub, M.J.; Dabdoub, V.M.; Comasseto, J.V. Tetrahedron Lett. 1992, 23, 2261.

42. (a) Pereyre, M.; Quintard, J.P.; Rahm, A. In Tin in Organic Synthesis; Butterworths, London, 1987, 23, 154; (b) Labinger, J.A. In Comprehensive Organic Synthesis; Fleming, J., ed.; Pergamon Press; Oxford, 1991, v. 8, 667; (c) Eisch, J.J. In Comprehensive Organic Synthesis; Fleming, J., ed.; Pergamon Press; Oxford, 1991, v. 8, 733.

43. (a) Ogawa, A.; Tsuboi, Y.; Obayashi, R.; Yokoyama, K.; Riu, I.; Sonoda, N. J. Org. Chem. 1994, 59, 1600; (b) Chieffi, A.; Comasseto, J.V. Synlett 1995, 671; (c) Tetrahedron Lett. 1994, 35, 4063; (d) Mo, X.S.; Huang, Y.Z. Synlett 1995, 180.

44. (a) Sharpless, K.B.; Gordon, K.M.; Lauer, R.F.; Patrick, D.W.; Singer, S.P.; Young, M.W.; Chem. Scripta 1975, 8A, 9; (b) Lee, H.; Cava, M.P. J. Chem. Soc., Chem. Commun. 1981, 277; (c) Uemura, S.; Fukuzawa, S.I. J. Am. Chem. Soc. 1983, 105, 2748; (d) Uemura, S.; Hirai, Y; Ohe, K.; Sugita, N. J. Chem. Soc., Chem. Commun. 1985, 1037; (e) Uemura, S.; Ohe, K.; Fukuzawa, S.I. Tetrahedron Lett. 1985, 26, 895.

45. (a) Nishibayashi, Y.; Komatsu, N.; Ohe, K.; Uemura, S. J. Chem. Soc., Perkin Trans I 1993, 1133; (b) Nishibayashi, Y.; Chiba, T.; Singh, J.D.; Uemura, S. J. Organomet. Chem. 1994, 473, 205.

46. (a) Uemura, S.; Fukuzawa, S.I.; Ohe, K.; Tetrahedron Lett. 1985, 26, 921; (b) Chiba, T.; Nishibayashi, Y.; Singh, J.D.; Ohe, K.; Uemura, S. Tetrahedron Lett. 1995, 36, 1519.

47. (a) Osuka, A.; Mori, Y.; Shimizu, H.; Suzuki, H. Tetrahedron Lett. 1983, 24, 2599; (b) Huang, X.; Xie, L.; Wu, H. J. Org. Chem. 1988, 53, 4862; (c) Osuka, A.; Hanasaki, Y.; Suzuki, H. Nippon Kagaku Kaishi 
1987, 1505; (d) Li, S.W.; Zhou, Z.L.; Huang, Y.Z.; Shi, L. L. J. Chem. Soc., Perkin Trans. I 1991, 1099. 48. (a) Osuka, A.; Suzuki, H. Tetrahedron Lett. 1983, 24, 5109; (b) Shi, L.L.; Zhou, Z.L.; Huang, Y.Z. Tetrahedron Lett. 1990, 31, 4173; (c) Zhou, Z.L.; Huang, Y.Z.; Shi, L.L; Hu, J. J. Org. Chem. 1992, 57, 6598.

49. (a) Luppold, M.; Müller, E.; Winter, W.Z. Naturforsh 1976, 31b, 1654; (b) Kauffmann, T. Angew. Chem. Int. Ed. Engl. 1982, 21, 410; (c) Hiiro, T.; Kambe, N.; Ogawa, A.; Miyoshi, N.; Murai, S.; Sonoda, N. Angew. Chem. Int. Ed. Engl. 1987, 26, 1187; (d) Barros, S.; Comasseto, J.V.; Berriel, J. N. Tetrahedron Lett. 1989, 30, 7353; (e) Kanda, T.; Kato, S.; Sugino, T.; Kambe, N.; Sonoda, N. J. Organomet. Chem. 1994, 473, 71; (f) Kanda, T.; Ando, Y.; Kato, S.; Kambe, N.; Sonoda, N. Synlett 1995, 745; (g) Hiiro, T.; Morita, Y.; Inoue, T.; Kambe, N.; Ogawa, A.; Ryu, I.; Sonoda, N. J. Am. Chem. Soc. 1990, 112, 455; (h) Hiiro, T.; Atarashi, Y.; Kambe, N.; Fujiwara, S.I.;
Ogawa, A.; Ryu, I.; Sonoda, N. Organometallics 1990, 9, 1355.

50. Kanda, T.; Sugino, T.; Kambe, N.; Sonoda, N. Phosphorus, Sulfur and Silicon 1992, 67, 103.

51. Terao, J.; Kambe, N.; Sonoda, N. Tetrahedron Lett. 1996, 37, 4741.

52. (a) Tucci, F.C.; Chieffi, A.; Comasseto, J.V. Tetrahedron Lett. 1992, 33, 5721; (b) Tucci, F.C.; Chieffi, A.; Comasseto, J.V.; Marino, J.P. J. Org. Chem. 1996, 61, 4975; (c) De Araujo, M.A.; Comasseto, J.V. Synlett 1995, 1145.

53. Clive, D.L.J.; Anderson, P.C.; Moss, N.; Singh, A. J. Org. Chem. 1982, 47, 1641.

54. (a) Barton, D.H.; Ozbalik, N.; Sarma, J.C. Tetrahedron Lett. 1988, 29, 6581; (b) Barton, D.H.R.; Ramesh, M. J. Am. Chem. Soc. 1990, 112, 891; (c) Barton, D.H.R.; Dalko, P.J.; Géro, S.D. Tetrahedron Lett. 1991, 32, 4713.

55.Engman, L.; Gupta, V. J. Org. Chem. 1997, 62, 157.

FAPESP helped in meeting the publication costs of this article 